\title{
Influence of Home Environment on Academic Performance of Secondary School Students in Agricultural Science in Adamawa State Nigeria
}

\author{
Egunsola, A. O. E. (PhD) \\ Department of Vocational Education School of Technology and Science Education Modibbo Adama University \\ of Technology, Yola Adamawa State Nigeria
}

\begin{abstract}
This study used ex-post facto and correlation survey to investigate the influence of home environment on academic performance of senior secondary students in Adamawa State. The population of the study consisted of 8,548 students in class 2 in 2012/13 to 2013/14 academic sessions. A total sample of 900 students was drawn from the population using multi-stage random sampling technique to respond to the instrument for data collection for the study. The instrument was a 40 item researcher designed questionnaire titled Home Environment Factors and Students' Academic Achievement Test in Agricultural Science (HEFSAATAS) consisting of two sections $A$ and B. Inferential statistics z-test and Correlation analysis were used to analyse and interpret the data. The results showed that parental educational qualification $(r=0.73)$, occupation $(r=$ $0.71)$ and home location $(r=0.73)$ were highly correlated with students' academic performance while parental economic status (income and affluence) have moderate correlation $(r-0.60)$ but all the independent variables have significant influence on students' performances in Agricultural Science at the secondary school. It was recommended that parents and other significant persons should make students' homes conducive and stimulatory to learning not only the school subjects but education in general.
\end{abstract}

Key Words: Home, Environment, Academic, Achievement

\section{Introduction}

The menace of academic failure among the young school graduates has stared both the government and stakeholders in the face. There is a consensus of opinion about the fallen standard of education as a big problem that is hindering the posterity of the Nigerian nation in terms of quality man power resources. Most students in secondary school experience academic problem that manifests itself in the form of academic poor performance. Many researchers have sought to find out the reasons for the downward trend in the academic performance of secondary school students. Adesehinwa (2013) reported effect of family type and poor funding on students' academic achievement; Ogbemudia and Aiasa (2013) reported lack of good home foundation for pupils as cause of poor performance by students; Achieng (2012) found home factors, student factors and institutional capacity as the causes while Adesehinwa and Aremu (2010) posited that factors resident in child, family, society, government and the school may be composite causative effects for these downtrend; they, however concluded that there is a need for each of these variables to be considered extensively, hence the focus of this study to critically consider influence of home on academic performance of secondary school students. Other studies showed that the level of family cohesion (Caplan et al, 2002 cited in Diaz, 2004), and family relationships (Buote, 2001) proved themselves capable of predicting performance.

Over a period of time, it has been observed that students exposed to the same lessons by the same teachers perform differently when they are evaluated (Adesehinwa, 2013). This shows that outside the school environment, other factors influence students' academic performance. Also differences in the academic performances of gifted and non gifted children cannot be traced to school environment (Adesehinwa and Aremu, 2010). Hence, many other uncontrolled variables can be responsible for academic performance of students generally, secondary school students inclusive. Schiefelbaum and Simmons (2000) cited by Adell, (2002) consider family background the most important and most weighty factor in determining the academic performance attained by the student. Among family factors of greatest influence are social class variables and the educational and family environment. Emeke (1984) stressed that the environmental condition and the nature of social interaction that goes on in the family may have some positive or negative influence on the academic achievement of a child. One of the tasks of Education is to train young people to become useful members of the society and this training begins at home in the informal way. The home of the child is the first place he/she enters when born into the world by parents.

A home is a place where pupils live with their parents or guardian and it is the place where they are groomed. It is a place where the pupils begin to learn the norms and values of the society in which they find themselves. The family is a social unit in any society and it is the source of early stimulation and experience in 
children (Collins, 2007). The home influences the child at the most earliest possible time of his life at a time when his mind is most receptive. It provides the first impression which may last through the whole life of the child. The child often sees the parents, siblings and things in their immediate environment to be most significant and they are capable of promoting or diminishing him in self worth and academic performance (Ekanem, 2004).

The family, being a powerful influence on the child and its importance as a primary agent of socialization could in no doubt enhance or hinder the academic achievement of the child depending on the social climate in the family. Variance in psycho-social emotional fortification in the family background could be an indicator to high or low academic performance of students, bearing in mind the intervening effect of high and low socio-economic status and emotional stability of students which is a pre-requisite to academic achievement (Adebule, 2004). This is because psychological problems are potential sources of trouble with learning. It is therefore against these backgrounds that this study sought to determine influence of home environment on academic performance of secondary school students in Adamawa State.

The environment is the immediate surrounding in which the pupils find themselves. It is also referred to as the physical and psychological conditions that affect children (Ogbemudia and Aiasa, 2013). The parents or guardian of the students are responsible for providing the right home environment that will facilitate effective learning for their wards. Furthermore, in pupil's home environment, some factors that influences their academic performances include: parental educational background, occupation, economic status, marital status and home location; family size and peer group.

The home environment means the family background of the students; this includes all the human and material resources present at the home that affects the student's education and living, such as the parent's level of education, their occupation, socio-economic status and socializing facilities available in the house. Thus, the home is the basic institution for providing the child's primary socialization and laying the educational foundation for the child upon which the other agents of socialization are built. The education received by a child from parents and significant others at home is most likely to have a highly significant and dominant effects on the behaviours of the child later in life. What the child learns at home and how his/her family motivates him/her towards education contributes to the child's success or failure at school. Even though, environment also plays a very remarkable role in the life and educational success of every individual.

As a result of the need to train the young people, the Federal Government of Nigeria in 1976 produced a document - National Policy on Education (NPE) to guide and help the home and schools in bid to achieve this great task. The NPE contains the national objectives for education, secondary school education in particular should:

a. Provide all primary school graduates with the opportunity to further their education at a higher level irrespective of sex, religion or ethnic background

b. Cater for differences in interests, talents for opportunity and future roles

c. Preserve cultural heritage by developing and promoting the Nigerian languages, arts and culture

d. Foster national unity by emphasizing the divers common ties that unite Nigerians

e. Raise a generation of people who can think for themselves, respects the views and feelings of others, respects the dignity of labour, be a patriotic and good citizens.

Agricultural science teaching and learning (farming) has a long history of being Nigeria's cultural heritage passed on from one generation to the next by the fore fathers as a necessary vocation to maintain the food and fibre chains which were the main means of survival. Nowadays, farming business is no more interesting and attractive to the youths; youngsters who should be the future farmers do not value farming vocations despite all its multifarious benefits. Thus, many young people do not like going in to agricultural education because many regard agricultural studies and its allied vocations as a job and business for the less intelligent or poor academic achievers. But this is far from the reality! This is one of the reasons for dwindling students' enrolment in the Agricultural Science discipline and its associated fields of studies (Egunsola, 2012); thus, attracting quality students to choose agricultural science subject remains one of the most vital duty of agricultural educators.

Campbell and Martin (2003) reported that agricultural education has a long history in education (Nigeria inclusive), most programs consist of classroom and laboratory instruction, agricultural clubs. Students and teachers spend time in and outside the school following the curriculum and working on projects. Technological evolution has transformed the nature and vastly broadened the range of agricultural occupations and professional careers. Agriculture broadly defined, is the plants and animals providing our food and fibre and are part of a vast web of life that functions as an integrated whole. Every species of plant and animal depends not only on its physical environment, but on the biological component of the environment as well. All living creatures are part of the same cycles of matter and energy. Education will be incomplete unless students are exposed to learn what is essential for the lives of our crops, animals and plants (Myers et al., 2004). 


\section{Theoretical and Conceptual Perspectives}

This study was based on Cause and Effect Theory. Cause and effect describes how something happens, analyzes why something happens; examines cause, describes effect or do both because it links situations and events together in time, with cause preceding effect (Epp, 2004). Furthermore, causality refers to cause-andeffect analysis, it explains why something happened, or is happening and it predicts what probably will happen. Sometimes, many different causes may be responsible for one effect, and similarly, many different effects could be produced by a single cause. In logic, causes are often distinguished in to two types: necessary and sufficient. If $\mathrm{x}$ is a necessary cause of $\mathrm{y}$, then the presence of $\mathrm{y}$ necessarily implies the presence of $\mathrm{x}$. The presence of $\mathrm{x}$, however, does not imply that $\mathrm{y}$ will occur. If $\mathrm{x}$ is a sufficient cause of $\mathrm{y}$, then the presence of $\mathrm{x}$ necessarily implies the presence of $y$. However, another cause $z$ may alternatively cause $y$, thus the presence of $y$ does not imply the presence of $\mathrm{x}$ (Epp, 2004). Cause and effect is established through intervention trial in which two or more groups undergo the same experience except for a single facet. The single facet in this study is home environment. Any difference in outcome is then attributed to that single facet (Freedman, 1999). Causality (causation) denotes a logical relationship between one event (called cause) and another event (called effect) which is the direct consequence of the first (Sowa, 2000). The cause in this study is home environment while academic performance of student is the effect.

In this study, the researcher focused on how parental educational qualification (non-educated, graduate of primary, secondary, post secondary schools (undergraduates), university graduates or postgraduate); parent's economic status comprising of Income and affluence; (income - high, average and low) and (affluence - number of cars, television sets at home, computers and other social equipment and facilities available to the student at home); parent's occupation and home location influence academic performance of students in Agricultural Science at the secondary school level.

The educational background of the parents can be expressed in their frequent use of English Language as a medium of communication in the home (John 1994).This will help in laying a good foundation for self expression, confidence in speaking good English in the public and good understanding of basic English concepts in the school since English Language is used for communication in schools. Coon et al., (1993) found that parental Intelligence Quotient (IQ) influences child's achievement but both are linked mainly by School environment provided for the child. Schnabel and Schnabel (2002) also pointed out that parental educational levels are positively related to wages.

Gustafsson et al., (2011) reported that parental expectations and the parents' function as role models are important mediating mechanisms to account for the effects of Parental Education on pupil's achievement. However, they added that it is reasonable to expect that the number of books in the home can play an important part in such mediating mechanisms. They identified another path between Parental Education and achievement, which was unexpected, that is, the relationship between NumLitAct and Ability, which implies that in homes where there is stronger emphasis on literacy activities than numeric activities there is a positive effect on the ability to perform both numeric and literacy tasks at the beginning of primary school. In some instances, there was a direct effect (positive or a negative) of Parental Education on NumLitAct, while in others; there was an indirect effect via Books.

The influence of family educational climate is defined by the amount and the style of help that children receive from the family; that is determined by elements of the family context, like the dynamic of communication and affective relationships, attitudes toward values, expectations et cetera (Diaz, 2004). Along these same lines, Marchesi and Martin (2002) reported that parental expectations have a notable influence on academic results, even when controlling for initial knowledge and socio-economic context. Castejon and Perez (1998) found indirect relationships with performance from the student's perception of how much importance his or her parents assign to study at home.

On the aspect of parental economic status (income and affluence) as it relates to pupil's academic performance, much emphasis was laid on the ability of the parents to provide necessary facilities or materials that can help in making the learning of school subjects easy for the pupils. This involves the provision of mini library for children which include textbooks for English, Mathematics, and Agricultural Science and for all the other school subjects, story books, and picture books and spelling charts, which will help the pupils to learn words identification, correct spellings, correct sentences, master the use of correct tenses in line with pictures et cetera. Azikiwe (2008) maintained that the implementation of the reform/innovation cannot do so much if the basic instructional materials are in short supply.

In regard to parental occupation, a child from a well educated with high socio-economic status is more likely to perform better than a student from an illiterate family. This is because the child from an educated family has a lot of support such as a decent and good environment for academic work, parental support and guidance, enough textual and academic materials and decent feeding. He or she is likely to be sent to good schools where well seasoned teachers will handle his or her subjects (Akinsanya et al., 2011). According to Graetz, (2009) parental education and occupational status are highly correlated with children's educational 
choices and attainment; this implies that the higher the parental educational qualification, the higher the occupational status of such a parent; and vice versa. Graetz further reported that children from parents having low occupational status face a lot of barriers in transiting from one stage of education to the next; revealing that low parental occupational status has negative influence and effect on student's school achievement.

Family background variables, parental characteristics and attributes as well as how parents view the importance of education and what they actually do in terms of helping and guiding their children are all important factors in the child's success in the school system (McIntosh, 2008). Rothman (2004) reported the critical factors associated with student's achievement as socio-economic factors which include parental educational qualification, neighbourhood poverty, parental occupational status, and family income. He concluded that if we do not consider how educational policies complement of conflict with policies related to family welfare, work, poverty, housing and neighbourhood conditions, then we will continue to face significant obstacles in attaining the goal of narrowing the achievement gaps. This conclusion points to the fact that differences in socio-economic background of students breed achievement gaps.

From the submissions above, it is glaring that the parental occupational statuses go a long way to enhance or impede the type, quality and quantity of support parents can give to their wards that can amount to school achievement. The type of occupation also has significant influence on student's achievement in the school, because the type of engagement of the parent will determine the amount of time they can give attention to the student at home and the level of their involvement in their ward's educational programmes. A very busy parent who leaves home before daybreak and returns when the child is already asleep can offer very minimum attention and input to a child's education needs at home and in school.

In terms of the influence of home location on the academic performance of students, the researcher was concerned with the socio-metric factors such as the kinds of social activities around the home environment of the pupils. For instance, a pupil that lives near the market square will adopt the language of the people around the market. This could affect the child in learning good English at school. Furthermore, pupils from homes located in an environment where there is noisy traffic and noisy sound of machine from ply-wood industry will be affected negatively in their performance in School because the noisy environment will disturb them from concentrating while reading and studying at home and even in listening to educative radio programmes. Hence, Ogbemudia and Aiasa (2013) maintained that physical and psychological conditions of the home environment affect the children academically.

\section{Methodology}

The research designs used for this study were ex-post facto and correlation survey; because the study involves seeking opinion of students in their natural setting and correlating the findings. The area of study is Adamawa State. It is located within the North East Zone of Nigeria. According to Adebayo and Tukur (1999) Adamawa State lays between latitude $7^{\circ}$ and $11^{\circ}$ North of the equator and longitude $11^{\circ}$ and $14^{\circ}$ East of the Greenwich Meridian; with altitude of 185 meters above sea level. Adamawa State has twenty-one Local Government Areas, with land mass of $8,068 \mathrm{Km}^{2}$ (National Population Commission, 2006) and the State consist of five educational zones, namely, Ganye, Gombi, Mubi, Numan, and Yola respectively. All the secondary schools in the State are grouped under the five educational zones. There are many primary, secondary and tertiary schools in Adamawa State but this study is concerned only with the State Government owned senior secondary schools students.

The population of the study consisted of 8,548 senior secondary school students in class 2 in 2012/13 to 2013/14 academic sessions (Adamawa State Post Primary Schools Management Board (ADSPPSMB), 2013). A total sample of 900 students in senior secondary school class 2 (SSSS2) was drawn from the population using multi-stage random sampling technique; 15 students each from monogamous and polygamous family backgrounds in each selected school, giving 30 students per school and 6 schools in each of the five educational zones. Thus, the sample technique selected 450 students each from monogamous and polygamous family backgrounds to constitute the respondents in this study. This agrees with Toluhi (2001) who recommended a sample range of $10-30$ per cent of a population.

The instrument used to collect data for this study was a researcher designed questionnaire titled Home Environmental Factors and Students' Academic Achievement Test in Agricultural Science (HEFSAATAS) consisting of two sections A and B. Section A consisted of 15 home environmental factors items while section B was made up of 25 items for Students' Academic Achievement Test in Agricultural Science. The 40 questionnaire items covered all the objectives of the study and it required the respondents to indicate their opinion on level of influence of each factor on their academic performance. The instrument used a four-point scale, thereby, eliminating the option of no opinion $(4=$ very high influence; $3=$ moderate influence; $2=$ low influence; and $1=$ no influence). The instrument was validated (content and face validities) by three experts in the field of Agricultural Education, and it was field tested in a neighbouring State - Gombe, using 40 senior 
secondary School students in class 2 ; the instrument gave a reliability co-efficient of 0.78 using Cronbach Alfa. Inferential statistics z-test analysis and correlation were used to analyse and interpret the data.

\section{Results}

Hypothesis One: Parental educational qualification will not have any significant influence on students' academic performance in Agricultural Science at the secondary school The data that answered this hypothesis are presented on Table 1

Table 1: Correlation z-test analysis on influence of parental educational qualification

\begin{tabular}{llllllll}
\multicolumn{6}{c}{ On students' academic performance in Agricultural Science } \\
\hline Educational qualification (EQ) & $\mathrm{N}$ & $\mathrm{X}$ & $\mathrm{SD}$ & $\mathrm{df}$ & $\mathrm{r}$ & z-cal & Remarks \\
\hline 1. & Not educated & 60 & & & & & \\
2. & Primary school & 180 & & & & \\
3. & Secondary school & 300 & & & & \\
4. & Undergraduate & 255 & & & & \\
5. & University graduate & 90 & & & & \\
6. & Post graduate & 15 & & & & \\
Parental EQ & 900 & 13.8 & 3.16 & & & \\
& & & 898 & 0.73 & 41.4 & High correlation \\
Academic achievement & 900 & 25.1 & 1.76 & & & & \\
\hline
\end{tabular}

Significant at 0.05 level, degree of freedom $(\mathrm{df})=898$, z-critical $=1.96$

Hypothesis Two: Parental economic status (income and affluence) will not have any significant influence on students' academic performance in Agricultural Science at the secondary school

The data that answered this hypothesis are presented on Table 2

Table 2: Correlation z-test analysis on influence of parental economic status on students' academic performance in Agricultural Science

\begin{tabular}{lrrrrrrl}
\hline Income & $\mathrm{N}$ & $\mathrm{X}$ & $\mathrm{SD}$ & $\mathrm{df}$ & $\mathrm{r}$ & $\mathrm{z}$-cal & Remarks \\
\hline High & 80 & & & & & & \\
Average & 450 & & & & & & \\
Low & 370 & & & & & & \\
Parental income & 900 & 13.7 & 3.19 & & & & \\
& & & & 898 & 0.60 & 46.1 & moderate correlation \\
Academic achievement & 900 & 25.1 & 1.76 & & & & \\
\hline
\end{tabular}

Hypothesis Three: Parental occupation will not have significant influence on academic performance of students in Agricultural Science at the secondary school

The data that answered this hypothesis are presented on Table 3

Table 3: Correlation z-test analysis on influence of parental occupation on students' academic performance in Agricultural Science

\begin{tabular}{lcccccccc}
\hline Occupation & Hours at Work & $\mathrm{N}$ & $\mathrm{X}$ & $\mathrm{SD}$ & $\mathrm{df}$ & $\mathrm{r}$ & $\mathrm{z}$-cal & Remarks \\
\hline Full time & $8-12$ & 450 & & & & & & \\
Part time & $1-4$ & 280 & & & & & & \\
Not working & 0 & 170 & & & & & & \\
Parental occupation & 900 & 13.3 & 3.41 & & & & \\
& & & & 898 & 0.71 & 39.4 & High correlation \\
Academic achievement & 900 & 25.1 & 1.76 & & & & \\
\hline
\end{tabular}

Hypothesis Four: Home location of students' will not have any significant influence on academic performance of students in Agricultural Science

The data that answered this hypothesis are presented on Table 4

Table 4: Correlation z-test analysis on influence of home location on students' academic performance in Agricultural Science

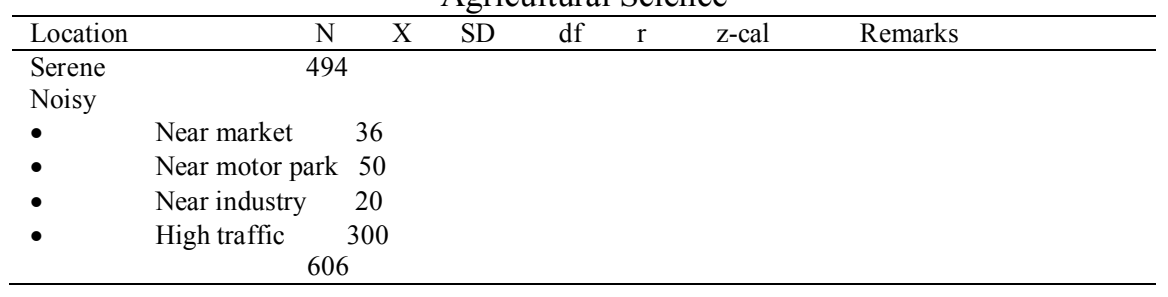


Influence of Home Environment on Academic Performance of Secondary School Students ....

\begin{tabular}{llllllll}
\hline Home location & 900 & 14.6 & 3.85 & & & & \\
& & & & 898 & 0.73 & 45.3 & High correlation
\end{tabular}

Academic achievement $900 \quad 25.1 \quad 1.76$

\section{Discussion}

The educational background of parents was highly correlated with and significantly influenced the academic performance of secondary school students. This finding is supported by the report of Coon et al (1993) that parental intelligence quotient is positively correlated with student's academic achievement. This revealed mainly the influence of parental involvement in and awareness of the pupil's involvement in educational activities right from home. This could also show the way parents and other educated people in the home get involve in encouraging the students to learn at home, teach and guide them in doing their home work, pronounce words correctly and practice how to make correct sentences in English Language.

Due to parental educational qualification they can afford a number of Books at Home, Number of Children's Books at Home, Father's Education, Mother's Education and Frequency of Reading/Talking with the Child all go a long way to indicate parental educational influence on their wards' academic achievement in school. Graetz (2009) reported that high parental education qualification translates to better occupations with higher economic status, Schnabel and Schnabel (2002) also pointed out that high educational qualification results to higher wages. Also, Gustafsson et al (2011) reported that parents' attitude towards reading and importance they attached to study serves as role models for their wards to perform well in school; all these are resultant influences of parental education background.

On the aspect of parental economic status (income and affluence) as it relates to pupil's academic performance, economic status of parents have moderate correlation with but significant on students' academic performance. Here much emphasis was laid on the ability of the parents to provide necessary facilities or materials that can help in making the learning of school subjects easy for the pupils. This involves the provision of mini library for children which include textbooks for English, Mathematics, and Agricultural Science and for all the other school subjects, story books, and picture books and spelling charts, which will help the pupils to learn words identification, correct spellings, correct sentences, master the use of correct tenses in line with pictures et cetera. This is why Azikwe (2008) opined that for continuous successful students' academic performance; basic materials needed by the students must not be in short supply. Rothman (2004) also reported that differences in socio-economic background of students breed achievement gaps.

This aspect helped the researcher to compare the academic performance of pupils from low, average, as well as high income parental background. Pupils from average/high income home environment that have some educative media in their homes such as Computer, television set, radio, tape recorder were at an advantage in their performances because these media helped them to listen to good speeches in English Language, watch educative programmes on television such as Teach your self Mathematics, junior debate, Cartoons, tales by moonlight, all these exposures will certainly reflect on the pupils performance at school. However, generally, when there is free access to education effect of parental background factors on student's achievement in the school is weak.

The result from this study showed that parental occupations have a high correlation and significant influence on students' academic performance in Agricultural Science among the respondents of this study. This finding is in agreement with the submissions of Akinsanya et al, (2011) that students endowed with high parental occupational backgrounds enjoy lots of parental support for academic work like decent feeding and provision of other necessary academic materials. The type of parental occupation also has significant influence on student's achievement in the school, because the type of engagement of the parent will determine the amount of quality time they can give attention to the student at home and the level of their involvement in their ward's educational programmes. A very busy parent who leaves home before daybreak and returns when the child is already asleep can offer very minimum attention and input to his or her child's education needs at home and in school. Graetz (2009) reported that parental occupation status is highly correlated with student's educational choices and attainment; low parental occupation status has negative influence and effect on students' school achievement; and, students having low parental occupation status face lots of barriers in transiting from one stage of education to the next.

Home locations have high correlation and significant influence on students' academic performance in Agricultural Science among the respondents of this study. This finding is supported by Ogbemudia and Aiasa (2013) who maintained that physical and psychological conditions of the home environment affect the children academically. This study discovers that when pupils homes are located in an environment where there is noisy traffic, noisy sound of machine from industry and market; these affect negatively students' performance in School because the noisy environment disturbs them from concentrating while reading and studying at home and even in listening to educative radio programmes. This is why Diaz (2004) emphasized on the importance, provision and influence of family educational climate that is conducive for learning; which is defined by the amount and the style of help that children receive from the family; that is determined by elements of the family 
context, like the dynamic of communication and affective relationships, attitudes toward values, expectations et cetera.

\section{Conclusion}

Based on the findings of this study, it was concluded that parental educational qualification, economic status, occupation and home location are correlated with and have significant influences on students' academic performance in Agricultural Science in Adamawa State secondary schools. These results are vital information for all stakeholders in educational administration, practice and evaluation to note, especially parents of students who are at the home front should support their ward's educational achievement by providing the right and most favourable home environment to enhance better school performance by the students.

\section{Recommendations}

Based on the findings of the study, the following recommendations were made:

1. Parents of students should yearn for higher educational qualification statuses since it will translate in to better occupations and higher wages, that is, higher economic statuses; thus better educational choices and offerings can be provided for their wards.

2. Parents and all the significant others at homes should make home environments to be learning stimulatory and study friendly for students.

3. Similar study may be replicated at other locations, at any other level of Nigeria's educational system in any part of the country.

\section{References}

[1]. Adamawa State Post Primary Schools Management Board (2013). Statistics unit

[2]. Adebayo, A. A. and Tukur, A. L. (1999). Adamawa State in maps. $1^{\text {st }}$ edition. Yola: Paraclete

[3]. Achieng, B. O. (2012). Influence of institutional capacity on academic performance of students in public secondary schools in Usigu Division - Bondo District Kenya. A Masters Thesis, University of Nairobi'

[4]. Adell, M. A. (2002). Estrategias para mejorar el rendimiento academicos des los adolescents. (Strategies for improving academic performance in adolescents). Madrid: Piramide

[5]. Adebule, S. O. (2004). Gender differences on a locally standardized anxiety rating scale in Mathematics for Nigerian secondary schools. Nign J. of Counselling and Applied Psychology, 1, 22 -29.

[6]. Adesehinwa, O. A. (2013). Effects of family type (monogamy or polygamy) on students' academic achievement in Nigeria. Intl J. of Psychology and Counselling, 5 (7), 153 - 156 DOI 10.5897/IJPC10.012 ISBN 2141 - 2499

[7]. Adesehinwa O. A. and Aremu, A. O. (2010). The relationship among predictors of child, family, school, society and the government and academic achievement of senior secondary school students in Ibadan, Nigeria. Procedia Soc. Behav. Sci. 5, $842-$ 849 .

[8]. Akinsanya, O. O., Ajayi, K. O. and Salomi, M. O. (2011). Relative effects of parentaloccupation, qualification and academic motivation of wards on students achievement in senior secondary school mathematics in Ogun State. British J. of Arts and Soc. Sc., 3(2), 242 - 252. ISBN: 2046 - 9578

[9]. Azikwe, U. (2008). Reforms in Education and future of Nigeria sociological perspective. Nig. J. of Educ. and Devt, Studies (AJEDC), 1(2): $10-12$

[10]. Bouote, C. A. (2001). Relations of autonomy and relatedness to school functioning and psychological adjustment during adolescence. Dissertation Abstracts International Section A: Humanities and Soc. Sc., 62 (1), 120 - 128.

[11]. Campbell, S. M. and Martin, R. A. (2003). Agricultural Education. Encyclopedia of Education. Encyclopedia.com 8 Jun. 2011 http://www.encyclopedia.com

[12]. Castejon, J.L. and Perez, A.M. (1998). Un mudelo casual-explicato de las variables psicosociales en el rendimiento academic. (A causal-explicative model of psycho-social variables in academic performance). Revista Bordon, 50 (2), $171-185$.

[13]. Collins, A. I. (2007). Social Studies for Schools. Ibadan: University Press Ltd.

[14]. Coon, H., Carey, G., Fulker, D. W. and Defries, J. C. (1993). Influence of environment on the academic scores of adopted and non - adopted children. Intelligence, 17:79-104

[15]. Diaz, A. L. (2004). Personal, family, and academic factors affecting low achievement in secondary school. Electronic J. of Res. in Ed. Psychology and Psychopedagogy, 1 (1), 43 - 66. ISBN 1696-2095

[16]. Egunsola, A.O.E. (2012). Assessment of factors influencing students' choice of Agricultural Science in senior secondary Schools in Gombe State, Nigeria. Ahmadu Bello University J. of Voc. Studies; 6 (1); 59 - 65.

[17]. Ekanem, T. F. (2004). The school as a substitute home in Q. I. Obinaju (Ed), Theory and Practice in Early childhood Education. Calabar; Nigeria, BON Ltd.

[18]. Emeke, E. A. (1984). Relationship between personal problems and study habits. J. Appl. Psycho., 3, 113 - 129.

[19]. Epp, S. S. (2004). Discreet Mathematics with Applications. 3rd ed. New York:

[20]. Brooks/Cole-Thomson.

[21]. Federal Government of Nigeria (1976). National policy on education. Lagos: NERDC

[22]. Freedman, D, (1999). From association of causation: some remarks on the history of

[23]. statistics. Statistical Science, 14, $243-258$.

[24]. Graetz, G. (2009). Parental background and transition to secondary school: evidence from Germany EC 331 Quantitative Economics Project

[25]. Gustafsson, J., Hansen, K. Y. and Rosen, M. (2011). Effects of home background on students achievement in reading, mathematics and science at fourth grade. Relationship Report, TMSS \& PIRLS 2011 nInternational Study Centre, $101-288$.

[26]. John, E. (1994). Multilingualism. London: Penglin Books Ltd.

[27]. Marchesi, A. and Martin, E. (eds). (2002). Evaluacton de la educacion secundaria,

[28]. Fotografia de una etapa polemica. (Evaluation in secondary education, Snapshot from a controversial era) Instituto IDEA, Madrid: SM 
[29]. McIntosh, J. (2008). Family background, parental involvement, and academic achievement in Canadian schools. J. of Econ Lit. Classification Numbers: $120 \mathrm{~J} 62$

[30]. Myers, B. E., Brejah, L. M. and Dyer, J. E (2004). Solutions to recruitment issues of High School Agricultural Education programs. J. of Agr. Ed., 45 (4): $12-21$.

[31]. National Population Commission (2006). Nigeria's National Census, Abuja: NPC Press.

[32]. Ogbemudia, M. I. and Aiasa, M. V. (2013). Influence of home environment on the academic performance of primary five pupils' in English Language in Orhionmwon Local Government Area of Edo State. Merit Res. J. of Ed. and Rev., 1 (5), 120 - 125.

[33]. Rothman, J. M. (2004). A study influencing attitudes towards science of junior high school students: Mexican - American pupils. J. of Res. in Sc. Tchg, 66 (1), $40-54$.

[34]. Schnabel, I. and Schnabel, R. (2002). Family and gender still matter: the heterogeneity of returns to education in Germany. Centre for European Economic Research Discussion; Paper No. $02-67$.

[35]. Sowa, J. F. (2000). Processes and Causality. London, Wiley \& Sons.

[36]. Toluhi, J. O. (2001). Fundamental of research methodology. Ilorin: Nigeria, Victory Publn. 